\title{
Spatial and temporal patterns of macroinvertebrates in drift and on substrate of a mountain stream (Cordoba, Central Argentina)
}

\author{
Padrôes espaciais e temporais de macroinvertebrados em deriva e em substrato de un \\ riacho da montanha (Córdoba, região central da Argentina)
}

María Daniela Barbero, Ana María Oberto and Cristina Mabel Gualdoni

\author{
Departamento de Ciencias Naturales, Universidad Nacional de Río Cuarto - UNRC, \\ X5804BYA Río Cuarto, Córdoba, Argentina \\ e-mail: mdanielabarbero@gmail.com; aoberto@exa.unrc.edu.ar, cgualdoni@exa.unrc.edu.ar
}

\begin{abstract}
Aims: The aims of this study are to evaluate the effects of spatial and temporal variability of the macroinvertebrate fauna in drift and in the substrate of a mountain stream. Methods: The study site is located in Achiras stream (Central, Argentina). This is an endorheic fluvial course whose headwaters are located in the southern extreme of Los Comechingones Mountains. Three replicate Surber samples were collected from benthos with $300 \mu \mathrm{m}, 0.09 \mathrm{~m}^{2}$ nets. Three drifting fauna samples were collected using drift nets, $1 \mathrm{~m}$ long, $300 \mu \mathrm{m}$ and $0.0192 \mathrm{~m}^{2}$. The taxonomic identification of specimens was performed according to the lowest possible taxonomic level. In order to characterize the drifting and benthic fauna, total abundance, taxonomic richness, Shannon and evenness indices were estimated and they were tested with two-way analysis of variance (ANOVA). In order to assess the distribution patterns of drift and benthos samples, we performed Canonical Correspondence Analysis (CCA). Results: A total of 61 taxa were identified in drift and 82 in benthos. A $26.3 \%$ taxonomic similarity between the two assemblages was observed, according to the Jaccard index. In drift and benthos, Arthropoda presented higher abundance and Insecta contributed with more taxa and it was also the most abundant. The most abundant orders were Ephemeroptera, Trichoptera and Diptera. In the present study, Anacroneuria sp. (Perlidae) and Podonominae (Chironomidae) were first recorded for benthic community of Achiras stream. Conclusion: In this study we found that the structural organization of the drifting and benthic macroinvertebrate community shows different patterns of variation at spatial and temporal scales.
\end{abstract}

Keywords: benthic community, drifting macroinvertebrates, fluvial habitats.

Resumo: Objetivos: Os objetivos deste estudo são avaliar os efeitos da variabilidade espacial e temporal sobre a fauna de macroinvertebrados em deriva e no substrato de um riacho de montanha. Métodos: A área de estudo situa-se no riacho Achiras (região Central da Argentina). Este riacho é endorréico e suas fontes estão localizados no extremo sul das serras de Comechingones. Foram coletadas três amostras de bentos com a rede de Surber de $300 \mu \mathrm{m}$ e $0.09 \mathrm{~m}^{2}$. Em deriva, foram coletadas três amostras com redes de $1 \mathrm{~m}$ long, $300 \mu \mathrm{m}$ e $0.0192 \mathrm{~m}^{2}$. A identificação taxonômica dos organismos foi feita até o menor nível taxonômico possível. A fim de caracterizar a fauna em deriva e a fauna associada ao fundo foram estimadas a abundância total, a riqueza taxonômica e os índices de equitabilidade e Shannon e eles foram testados com uma forma de análise de variância (ANOVA). A fim de avaliar os padrōes de distribuição de deriva e amostras de bentos, foi realizada análise de correspondência canônica (CCA). Resultados: Um total de 61 táxons foram identificados na deriva e 82 nos bentos. Observamos semelhança taxonómica de $26.3 \%$ dentre os dois conjuntos, de acordo com o índice de Jaccard. Na deriva e bentos, os artrópodes apresentaram a maior abundância. Insecta contribuiu com o maior número de táxons. As ordens mais abundantes foram Ephemeroptera, Trichoptera e Diptera. Anacroneuria sp. (Perlidae) e Podonominae (Chironomidae) foram registrados pela primeira vez para a comunidade bentônica do riacho Achiras. Conclusáo: Neste estudo, constatamos que a organização estrutural da deriva e da comunidade de macroinvertebrados bentônicos exibiu diferentes padróes de variação em escalas espaciais e temporais.

Palavras-chave: comunidade bentônica, macroinvertebrados à deriva, habitats fluviais. 


\section{Introduction}

Rivers and streams unidirectional flow continuously transport benthic invertebrates downstream (Waters, 1965; Hynes, 1970). The organisms that temporarily leave the streambed and do not resist the drag strength constitute the drift fraction. One important property of drift is the fact that it homogenizes genetically different populations and facilitates the repopulation of areas partially or totally denuded by floods, drought or contamination (Svendsen et al., 2004).

The study of drift process has increased in recent decades because of the importance of this phenomenon in the fish feeding ecology (Stark et al., 2002; Leung et al., 2009); in the effect of pesticides (Gladsø and Raddum, 2002; Jergentz et al., 2004 a, b) and in the interpretation of landscape changes as a consequence of human actions (Svendsen et al., 2004).

Drift components differ from the benthic components because not all organisms have the same predisposition to drifting. The drift composition reported for temperate regions indicates that Ephemeroptera, Diptera larvae, Plecoptera and some Trichoptera (those which build nets or light cases) dominate the drift fraction in this order. Amphipods, isopods and oligochaetes are also present (Allan, 1995).

The drift in lotic ecosystems can be studied taking into consideration different scales in time (both daily and seasonal ones) and space. Traditionally, the drift phenomenon has been studied on a limited spatial scale such as one river (Svendsen et al., 2004) or at stream reach level. However, research on changes in composition and structure between fluvial habitats and the factors contributing to this variation is scarce (Leung et al. 2009; Boyero and Bosch, 2002; Brooks et al., 2005). Drift studies conducted in Córdoba province (Argentina) have shown that, in a braided river reach, mayflies, chironomids and oligochaetes were the dominant groups with a distinct seasonal variation (Gualdoni et al., 1991; Corigliano et al., 2001). Principe and Corigliano (2006) analyzing the constant drift in a lowland river stretch, noted significant differences in composition and structure during the four seasons. Studies on behavioral drift both in plain and mountain rivers demonstrated the existence of temporal patterns, both daily and seasonal, dependent on species and zonal conditions (Oberto et al., 2004). However, studies on the process of constant drift for mountain streams is still lacking in Argentina.
Stream habitats differ in hydraulic conditions, caused by the flow velocity, depth and substrate type, all of which influence the spatial arrangement of benthic macroinvertebrates. Also, during the high water periods, precipitation causes the scouring of stream environments, reducing the abundance of organisms. Therefore, we expect the composition and structural attributes of benthos and drift to be different in run and riffle in the four seasons. We hypothesize the composition and structural attributes of benthic community and drift to be different in run and riffle in the four seasons. Therefore, we expect that both the benthic community and the drift fraction densities will be greater in low water period, and the taxonomic richness and diversity will be higher in riffle habitat. Finally, the taxonomic similarity between the two assemblages will be low. So the objectives of this study are to assess the composition and structure of the drift and benthic community in Achiras stream, and to analyze their spatial and seasonal variations.

\section{Material and Methods}

\subsection{Study area}

The study was carried out in the ritronic area of Achiras stream, altitude $810 \mathrm{~m}$ a.s.l., between $33^{\circ} 09^{\prime} 23.78^{\prime \prime} \mathrm{S}$ and $64^{\circ} 59^{\prime} 08.54^{\prime \prime} \mathrm{W}$ (Figure 1). This endorheic fluvial course drains an area of $750 \mathrm{~km}^{2}$. Headwaters are in the southern extreme of Los Comechingones mountains, which are located in the southwest of Córdoba province (Central Argentina). Achiras stream flows more than $130 \mathrm{~km}$ to its drainage in the Tigre Muerto wetlands, located $60 \mathrm{~km}$ south of Río Cuarto city. In the mountain area, this stream receives the input from numerous permanent and temporary tributaries, generating a dendritic fluvial drainage net. The climate is mesothermal, the average annual temperature ranging from 12 to $12.5^{\circ} \mathrm{C}$ (Valenzuela et al., 1998).

Achiras stream is a highly dynamic pluvial system. The precipitation reaches $940 \mathrm{~mm}$ per year and $77 \%$ of it concentrates in spring and summer. Spring usually manifests late. Therefore, there is a difference between high water period (rainy) from one of low water (dry), typical of temperate climates (Degiovanni, 2005).

\subsection{Field and laboratory methods}

Sampling was carried out in a reach of about $100 \mathrm{~m}$, in run and riffle habitats, during the months of May (autumn), September (winter), November (spring) and March (summer). Three samples were 


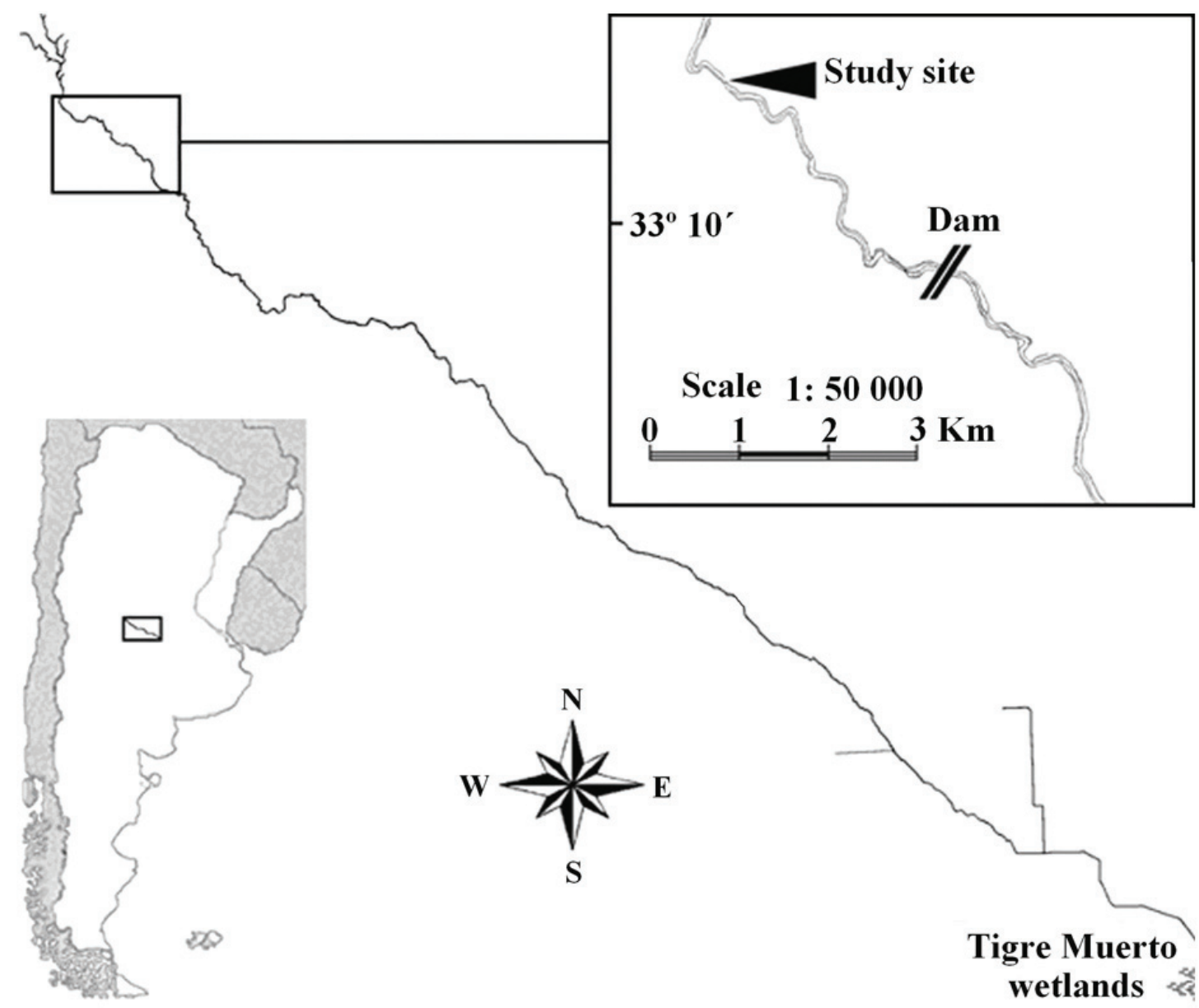

Figure 1. Study site location in Achiras stream, Córdoba province, Central Argentina.

collected from benthic community with Surber nets $\left(300 \mu \mathrm{m}, 0.09 \mathrm{~m}^{2}\right)$. Three drift samples were collected using drift nets similar to those suggested by Elliott (1970) ( $1 \mathrm{~m}$ long and $300 \mu \mathrm{m})$ modified to suit the studied stream characteristics. Achiras stream is remarkably shallow during the dry season in relation to the high water period. For this reason, we reduced the height of the frame suggested by Elliot (1970) from $0.04 \mathrm{~m}^{2}$ to $0.0192 \mathrm{~m}^{2}$. Drift nets were simultaneously placed in each habitat for 30 minutes in the middle of the water column thus preventing the capture of organisms that moved through the bottom as well as in the surface film. Drift samples were taken between $10 \mathrm{am}$. and $1 \mathrm{pm}$. in order to minimize the possibility of including behavioral drift organisms.

The taxonomic identification of specimens was performed to the lowest possible taxonomic level, according to the systematic knowledge of the freshwater regional fauna (Domínguez and Fernández, 2009). Biological data were expressed as drift density (number of individuals per $\mathrm{m}^{3}$ of water) and benthic density (number of individuals per $\mathrm{m}^{2}$ ).

In order to characterize the drift and benthic community, abundance, taxonomic richness, Shannon and evenness indices (using natural $\log$ ) were estimated. In this study, taxonomic richness was calculated instead of species richness (Malmquist et al., 2000), because not all identifications were made at the species level. The taxonomic similarity between drift and benthic community, and between run and riffle of both assemblages, was estimated by Jaccard index.

Depth and current velocity was measured with a current meter Global Flow Probe FP101FP202, for each sample (three times in each habitat unit). Suspended solids were estimated by Imhoff cone. The $\mathrm{pH}$, conductivity and temperature were measured with portable sensors. The daily precipitation data in the study area during the years 2007 and 2008 were provided by the meteorological station of Departamento de Geología, Universidad 
Nacional de Río Cuarto, located in the district of Achiras town.

\subsection{Data analysis}

Abundance, taxonomic richness, diversity and evenness of drift and benthic community were tested with two-way analysis of variance (ANOVA). We considered the habitat effect (run vs. riffle) and the seasons effect (autumn, winter, spring and summer). Posteriori comparisons were performed by Student-Newman-Keuls (SNK) test and Ducan test $(\mathrm{p} \leq 0.05)$. In order to normalize and homogenize variances, all data sets were transformed. Abundance data were $\log (x+1)$ transformed. We applied natural logarithm (ln) to taxonomic richness and densities of drift and benthos data. The statistical package used was INFOSTAT / PROFESSIONAL VERSION 1.1.

In order to assess the distribution patterns of drift and benthos samples, we performed Canonical Correspondence Analysis (CCA), using the program CANOCO Version 4.02 (ter Braak and Smilauer, 1999). Monte Carlo permutation test (499 permutations) was performed to determine the significance of the eigenvalues.

We selected eight abiotic variables: current velocity, depth, dry and wet width, water temperature, and structure of the bed substrate (rock, block, and pebble). The gravel and sand variables showed the highest correlation coefficient with other variables (inflation factor $>20$ ), and therefore, were not considered in the analysis. Taxa with density values less than $1 \%$ were excluded.

\section{Results}

\subsection{Environmental characteristics}

The hydraulic and physical variables between run and riffle are summarized in Table 1. The current velocity in both habitats was higher in summer. During the study period, precipitation was scarce in autumn, winter and spring (April 2007-December 2007), while there was a considerable increase in summer (January 2008-March 2008) (Figure 2). The average water temperature was $17 \pm 5^{\circ} \mathrm{C}$. The studied stream presented chemical features typical of a mountain unaltered fluvial course. The mean of all values indicated that the water was oligotrophic, slightly alkaline and hard (Table 2).

\subsection{Benthic and drifting macroinvertebrates}

A total of 61 taxa were identified in drift and 82 in benthic community. Both in drifting and benthic community, Arthropoda presented higher abundance (86\% and $75 \%$ respectively) and Insecta contributed with more taxa. During the four seasons the most abundant orders were Ephemeroptera, Trichoptera and Diptera (Figures 3 and 4). A 26.3\% taxonomic similarity between the two assemblages was observed, according to the Jaccard index. In drift, Americabaetis sp., Metrichia sp. and Simulium sp. were the most abundant. In benthic community, Americabaetis sp., Leptohyphes eximius Eaton 1882, Chimarra sp., Metrichia sp., Smicridea sp. and Simulium sp. exhibited high densities in the four seasons. Protoptila sp. and Mexitrichia sp. were present in winter, spring and summer. In both

Table 1. Hydraulic and physical characteristics in run and riffle in Achiras stream (Córdoba, Argentina). * By Hynes (1970).

\begin{tabular}{|c|c|c|}
\hline Habitat type & Run & Riffle \\
\hline Variables & mean \pm sd & mean \pm sd \\
\hline Dry width (m) & $10.08 \pm 2.23$ & $5.88 \pm 1.59$ \\
\hline Wet width (m) & $5.24 \pm 2.49$ & $3.33 \pm 0.89$ \\
\hline Depth (m) & $0.18 \pm 0.08$ & $0.24 \pm 0.08$ \\
\hline \multicolumn{3}{|l|}{ Current velocity (m/s) } \\
\hline Autumn & $2.19 \pm 1.55$ & $3.56 \pm 2.75$ \\
\hline Winter & $0.76 \pm 0.00$ & $1.03 \pm 0.00$ \\
\hline Spring & $1.62 \pm 0.00$ & $1.04 \pm 0.11$ \\
\hline Summer & $2.63 \pm 0.28$ & $4.71 \pm 1.93$ \\
\hline Discharge $\left(\mathrm{m}^{3} / \mathrm{s}\right)$ & $1.41 \pm 1.33$ & $1.27 \pm 1.02$ \\
\hline Suspended solids $24 \mathrm{~h}\left(\mathrm{~cm}^{3} / \mathrm{l}\right)$ & Traces & Traces \\
\hline${ }^{*}$ Rock (\%) & $0.00 \pm 0.00$ & $46.67 \pm 0.25$ \\
\hline${ }^{*}$ Block (\%) & $0.00 \pm 0.00$ & $46.67 \pm 0.31$ \\
\hline * Pebble (\%) & $13.33 \pm 0.14$ & $3.33 \pm 0.03$ \\
\hline${ }^{*}$ Gravel (\%) & $48.33 \pm 0.33$ & $1.67 \pm 0.01$ \\
\hline * Sand $(\%)$ & $38.33 \pm 0.33$ & $1.67 \pm 0.01$ \\
\hline
\end{tabular}




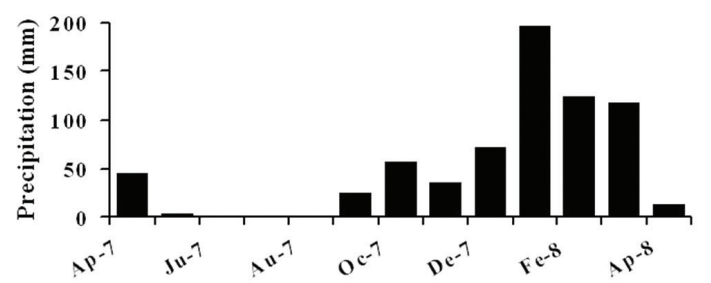

Figure 2. Total precipitation values $(\mathrm{mm})$ during the study period. The abbreviations Ap, Ju, Au, Oc, De and Fe correspond to the months. Ap: April, Ju: June, Au: August, Oc: October, De: December, Fe: February. The number 7 indicates year 2007, and the number 8 , indicates year 2008 .

Table 2. Water chemical composition of Achiras stream during the period studied.

\begin{tabular}{lc}
\hline \multicolumn{1}{c}{ Chemical variables } & mean \pm sd \\
\hline $\mathrm{pH}$ & $8.34 \pm 0.12$ \\
Conductivity at $25{ }^{\circ} \mathrm{C}(\mu \mathrm{S} / \mathrm{cm})$ & $208.67 \pm 32.35$ \\
Total dissolved solids $(\mathrm{mg} / \mathrm{L})$ & $183.33 \pm 12.10$ \\
Carbonate $(\mathrm{mg} / \mathrm{L})$ & $0.00 \pm 0.00$ \\
Bicarbonate $(\mathrm{mg} / \mathrm{L})$ & $105.00 \pm 6.61$ \\
Sulfate $(\mathrm{mg} / \mathrm{L})$ & $20.20 \pm 6.10$ \\
Chloride $(\mathrm{mg} / \mathrm{L})$ & $7.63 \pm 1.67$ \\
Sodium $(\mathrm{mg} / \mathrm{L})$ & $12.73 \pm 3.69$ \\
Potassium $(\mathrm{mg} / \mathrm{L})$ & $2.50 \pm 0.61$ \\
Calcium $(\mathrm{mg} / \mathrm{L})$ & $27.73 \pm 5.21$ \\
Magnesium $(\mathrm{mg} / \mathrm{L})$ & $5.37 \pm 1.45$ \\
Nitrate $(\mathrm{mg} / \mathrm{L})$ & $1.63 \pm 1.18$ \\
Nitrite $(\mathrm{mg} / \mathrm{L})$ & $0.00 \pm 0.00$ \\
Fluoride $(\mathrm{mg} / \mathrm{L})$ & $0.49 \pm 0.18$ \\
Arsenic $(\mu \mathrm{g} / \mathrm{L})$ & $1.33 \pm 0.58$ \\
Total hardness $(\mathrm{meq} / \mathrm{L})$ & $1.83 \pm 0.32$ \\
TAC alkalinity $(\mathrm{meq} / \mathrm{L})$ & $1.70 \pm 0.10$ \\
\hline
\end{tabular}

drift and benthos assemblages, during winter, Oligochaeta was incorporated. Some taxa such as Planorbidae, Lumbriculidae, Hydrometra argentina Berg 1879 and some flies larvae (Tipulidae, Limoniinae, Stratiomyidae and Nanocladius sp.) presented low densities and were rare in drift. In benthic community, Nanomis sp., Merragata sp., Ambrysus sp., Paratanytarsus sp., Podonominae and the stonefly Anacroneuria sp. were scarce.

Drift abundance was higher in run during winter and spring. The highest number of taxa recorded in run occurred in the spring. Diversity and evenness did not differ between run and riffle (Table 3 and Figure 5). The Jaccard index indicated a $65.6 \%$ taxonomic similarity between habitats. The greatest abundance of benthic macroinvertebrates was recorded in riffle during winter and spring. Taxonomic richness values showed the largest values in riffle in winter. Values in benthic diversity and evenness were minimal in run habitat during spring, while the lowest values occurred in the summer in riffle (Table 4 and Figure 6). In benthic community the Jaccard index between run and riffle was $68.3 \%$.

The CCA performed to the drift samples showed that they grouped in relation to environmental variables. The first four axes of the ordination explained $40 \%$ of total variability in the taxa data and $49.7 \%$ of the taxon-environment relationship (Eigenvalues: Axis 1: 0.123, Axis 2: 0.072, Axis 3: 0.022, Axis 4: 0.016; total inertia: 0.307). The restricted Monte Carlo permutation test showed that all axes were significant $(\mathrm{F}: 6.456, \mathrm{P}=0.02)$, indicating a good relationship between the distribution of drifting macroinvertebrate taxa and measured environmental variables. In the biplot graphic, axis 1 separated the autumn and summer samples, and the second axis separated the spring and winter ones, but showed no segregation of samples from run and riffle habitats (Figure 7). The CCA performed for drifting macroinvertebrates showed that Americabaetis sp., Caenis sp., Metrichia sp., Thienemannimyia sp., and Acariformes were associated with rock. Leptohyphes eximius, Simulium sp., Corynoneura sp., Cricotopus sp. 3 were associated with block, while Polypedilum sp., Rheotanytarsus sp. and Naidinae were associated to pebble (Figure 8).

The CCA performed with benthic data separated samples and taxa of run and riffle. The eigenvalues of the four axes were $0.065,0.045,0.026$ and 0.013 respectively, and the total inertia: 0.198 . The first axis explained $33 \%$ of the total variability in taxa data and the $40 \%$ of the taxon-environment relationship. The restricted Monte Carlo permutation test showed that all axes were significant (F: 7.304, $\mathrm{P}=0.02$ ), indicating a good relationship between the distribution of benthic macroinvertebrate taxa and environmental variables. The axis 2 separated run samples of the riffle ones, and it also segregated pebble from rock and block (Figure 9). The benthic taxa, Naidinae and Tanytarsus sp., were associated with pebble, while Smicridea sp., Metrichia sp., and Rheotanytarsus sp. were associated with rock and block (Figure 10).

\section{Discussion}

Our findings for the composition of the constant drift and benthic community of Achiras stream are consistent with existing data reported for other fluvial courses of medium order in the province of Córdoba, Central Argentina (Gualdoni et al., 1991; Principe and Corigliano, 2006). We found that both assemblages were dominated 

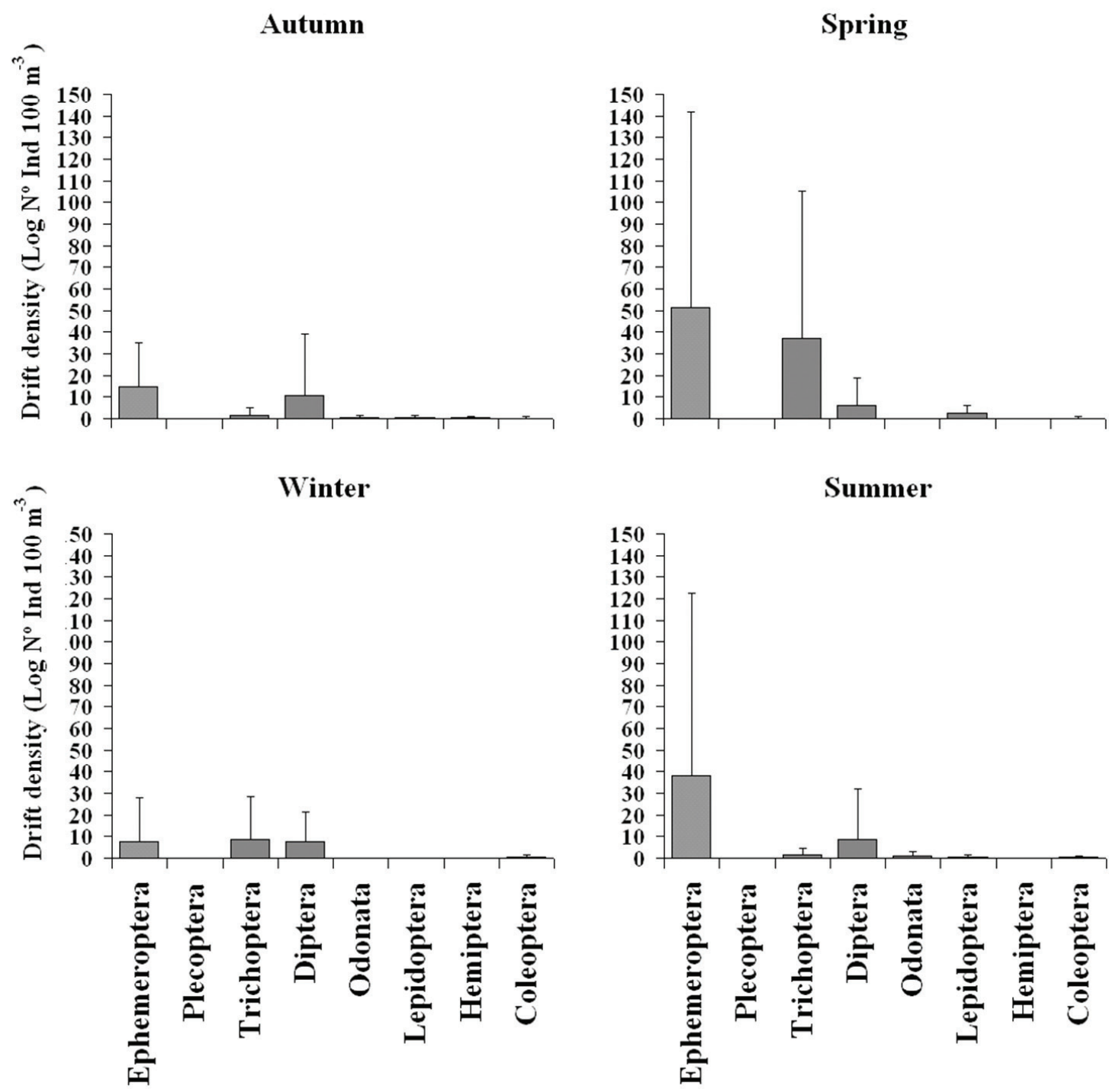

Figure 3. Drift density (Log $\mathrm{N}^{\circ}$ Ind $100 \mathrm{~m}^{-3}$ ) of the Insecta orders during the different seasons, in Achiras stream. Mean values and standard deviation are represented.

by Insecta and the most abundant orders were Ephemeroptera, Trichoptera and Diptera. The same insect taxa showed high densities in drift and benthic community in neotropical streams (Ramírez and Pringle, 1998b; 2001).

In the drift of Achiras stream some taxa showed low densities and were rare. In addition, mesoinvertebrates as Oligochaeta, Cladocera, Ostracoda and Copepoda increased the taxonomic richness. In benthic community, Podonominae (Chironomidae) and Anacroneuria sp. (Perlidae) were not abundant and were first recorded for Achiras stream. The presence of these taxa represents an important contribution because they increase the taxonomic richness and help to complement the baseline biodiversity information of a river system that had not been studied before. Its presence in the study site can be attributed to the remote benthos contribution. Protoptila sp. and Mexitrichia sp. (Glossosomatidae), which have low propensity to drift and have reduced mobility (Rader, 1997) were exclusive to benthic community. Our results indicate that the taxonomic similarity between drift and benthic community is low for Achiras stream. This is consistent with the fact that the drift integrates populations from different communities of a river section (Waters, 1965; 1972; Hynes, 1970).

Several authors studied seasonal variation of the structural attributes of the stream's macroinvertebrate communities in temperate climates (Gualdoni et al., 1991; Shearer et al., 2002; Leung et al., 2009) 


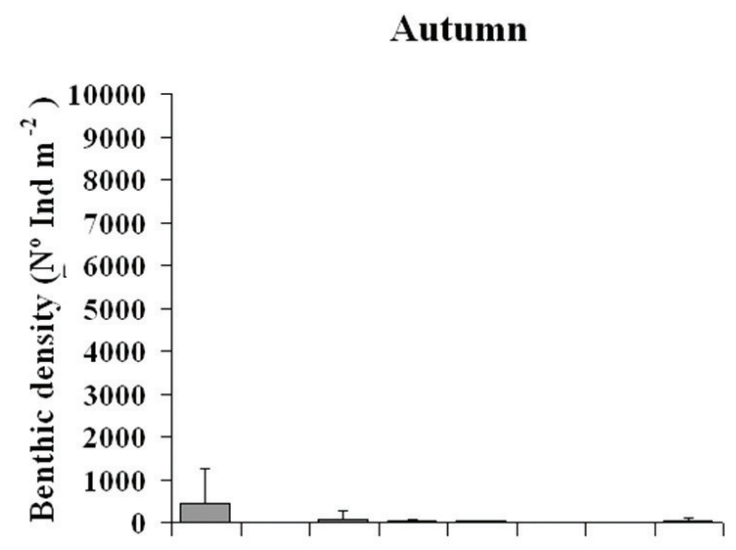

\section{Winter}

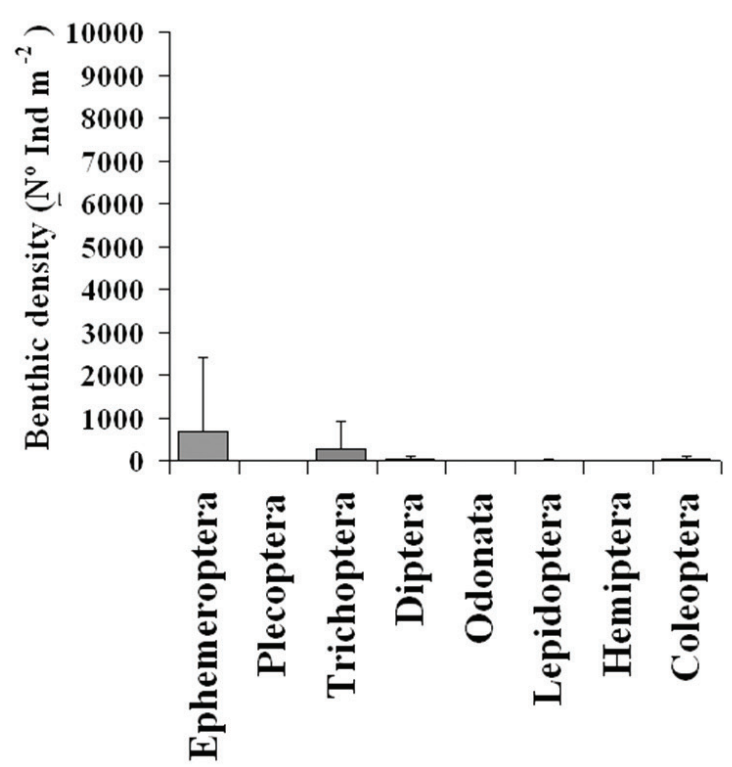

Spring

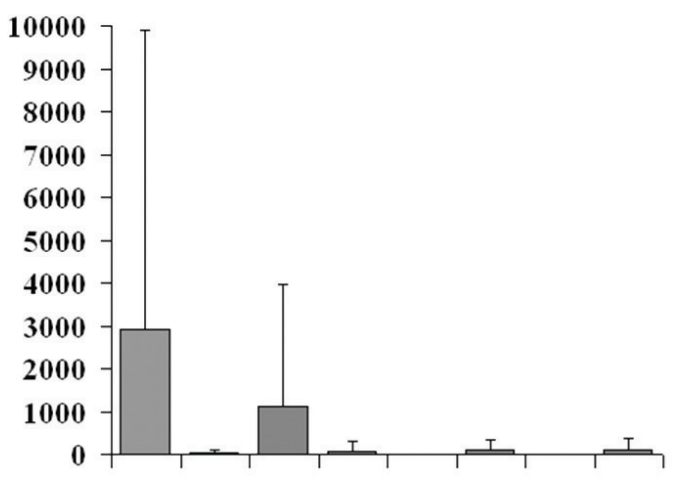

Summer

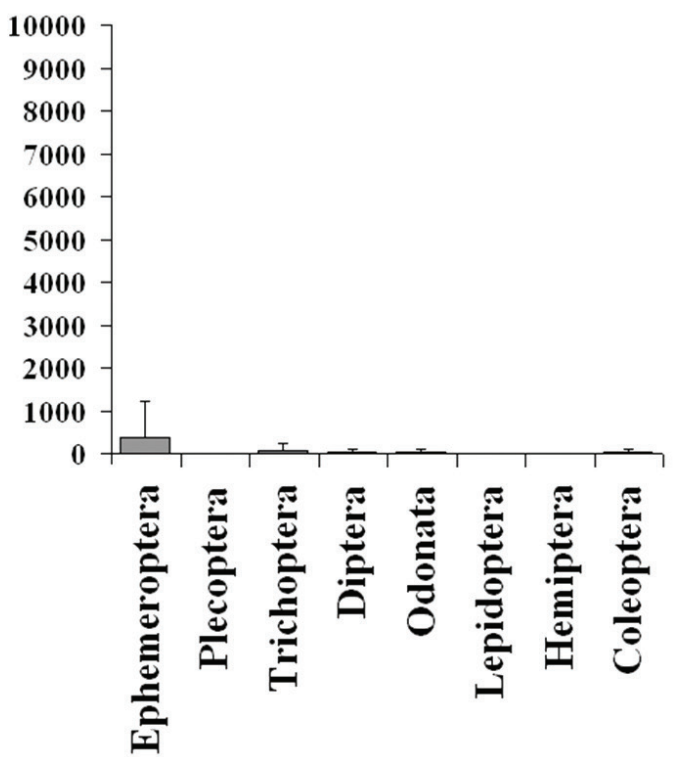

Figure 4. Benthic density (Log No Ind $\mathrm{m}^{-2}$ ) of the Insecta orders during the different seasons, in Achiras stream. Mean values and standard deviation are represented.

and found that they are dissimilar. Our results are in agreement with these studies, indicating that both assemblages, in run and riffle habitats, were significantly different across the seasons. The benthic community of Achiras stream showed higher values of abundance, taxonomic richness, diversity and evenness in winter and spring. In these seasons, hydrological stability conditions are established, so they enable stream organisms to have more time for colonization, which is expected to increase the number of taxa and their densities. Similar results were reported for a Neotropical stream by Ramírez and Pringle (1998a).

Regarding the drift density changes throughout the seasons, strong differences in numbers of drifting invertebrates have generally been reported by most studies (Svendsen et al., 2004). The magnitude of drift responses to changes in flow depends on the time in which the last fluctuation occurred (Corigliano et al., 1998). In stable hydrological conditions over prolonged time periods, organisms have higher opportunities to associate with specific microhabitats and thus increase their densities (Poff and Ward, 1991). In Achiras stream, the highest densities of drift were recorded in winter and spring, when the current velocity and precipitations exhibited the lowest values. Our results are consistent with those reported by other authors for Neotropical streams and rivers of medium order (Ramírez and Pringle 1998b; Corigliano et al., 1998). On the other hand, lower densities of drifting organisms were recorded during periods of 
Table 3. Results of ANOVAs showing the effect of habitat type and seasons on macroinvertebrates drift attributes. Significant $\mathrm{p}$ values are in bold.

\begin{tabular}{lccc}
\hline Source of variation & DF & $\mathbf{F}$ & $\mathbf{p}$ \\
\hline Total abundance & & & \\
Habitat & 1 & 8.66 & $\mathbf{0 . 0 0 9 6}$ \\
Season & 3 & 5.19 & $\mathbf{0 . 0 1 0 7}$ \\
Habitat x Season & 3 & 0.54 & 0.6592 \\
& & & \\
Taxonomic richness & & & \\
Habitat & 1 & 5.61 & 0.0308 \\
Season & 3 & 1.20 & 0.3424 \\
Habitat x Season & 3 & 3.78 & $\mathbf{0 . 0 3 1 7}$ \\
& & & \\
Shannon diversity & & & \\
Habitat & 1 & 1.09 & 0.3114 \\
Season & 3 & 6.20 & $\mathbf{0 . 0 0 5 4}$ \\
Habitat x Season & 3 & 0.31 & 0.8212 \\
& & & \\
Evenness & & & \\
Habitat & 1 & 3.79 & 0.0693 \\
Season & 3 & 4.66 & $\mathbf{0 . 0 1 5 9}$ \\
Habitat x Season & 3 & 0.54 & 0.6608 \\
\hline
\end{tabular}

high water conditions. Our results clearly segregated drift assemblage of low water period from high water assemblage. Considering the precipitations accumulated in periods prior to sampling, the drift density is low because the spates, caused by rains, denude the benthic community; therefore the high flows have a diluting effect on the bottom fauna (Corigliano et al., 1998).

Concerning the spatial variation of benthic community, several authors have analyzed its structure in different fluvial habitats (Principe, 2008; Gualdoni and Oberto, 2012). In Achiras stream the highest values of taxonomic richness, diversity and density corresponded to riffle, and the lowest values to run. Riffle habitats are more complex, offer numerous niches for stream bed macroinvertebrates, act as refuges from flooding and predators, and exhibit greater food supply (Principe, 2008). On the other hand, runs are fine-substrate habitats, unstable and poor in organic matter features that avoid the establishment and development of a rich and diverse benthic macroinvertebrate fauna. In our study, the CCA
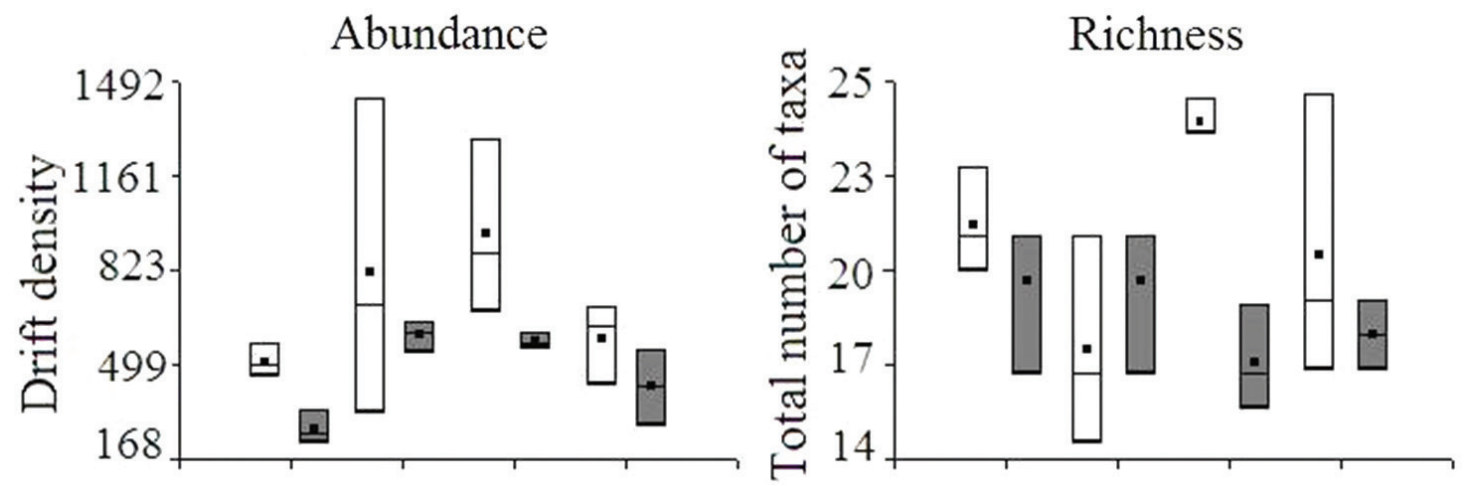

Eveness

Diversity
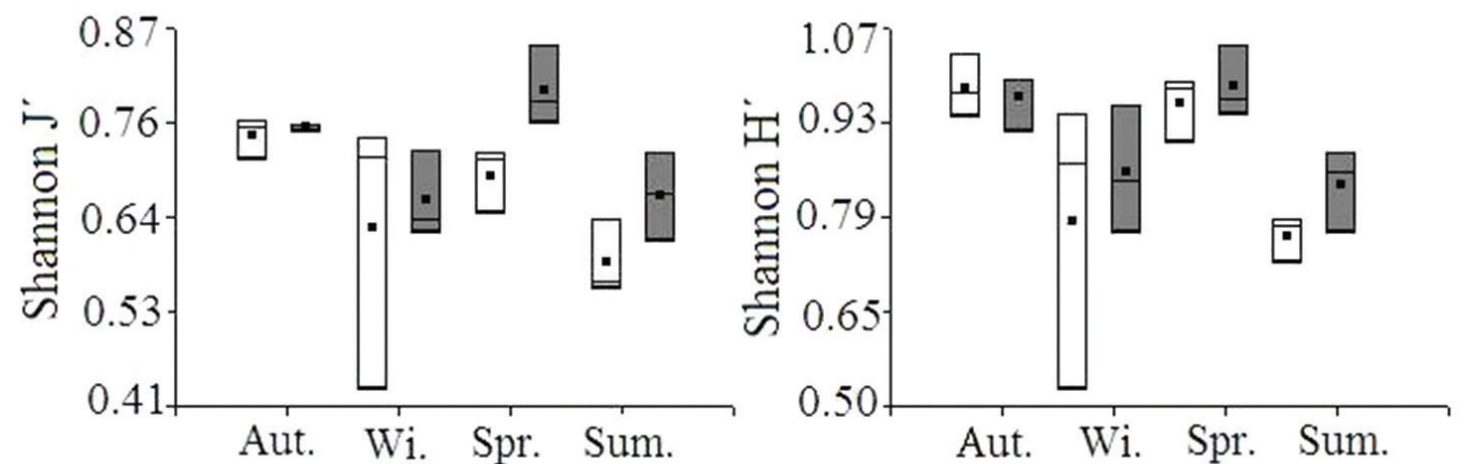

$\square$ Run $\square$ Riffle

Figure 5. Box plots for macroinvertebrate drift abundance, taxonomic richness, diversity and evenness in run and riffle of the study site. Seasons: autumn (Aut.), winter (Wi.), spring (Spr.) and summer (Sum.). 
Table 4. Results of ANOVAs showing the effect of habitat type and seasons on macroinvertebrate benthic community attributes. Significant p values are in bold.

\begin{tabular}{lcrc}
\hline Source of variation & DF & F & p \\
\hline Total abundance & & & \\
Habitat & 1 & 98.23 & $<0.0001$ \\
Season & 3 & 52.30 & $<0.0001$ \\
Habitat x Season & 3 & 5.26 & $\mathbf{0 . 0 1 0 2}$
\end{tabular}

\section{Taxonomic richness}

$\begin{array}{llrr}\text { Habitat } & 1 & 30.43 & <\mathbf{0 . 0 0 0 1} \\ \text { Season } & 3 & 5.13 & \mathbf{0 . 0 1 1 2} \\ \text { Habitat x Season } & 3 & 1.32 & 0.3024\end{array}$

$\begin{array}{llll}\text { Shannon diversity } & & & \\ \text { Habitat } & 1 & 8.81 & 0.0091 \\ \text { Season } & 3 & 2.03 & 0.1500 \\ \text { Habitat x Season } & 3 & 8.18 & \mathbf{0 . 0 0 1 6}\end{array}$

\begin{tabular}{lrrr} 
Evenness & & & \\
Habitat & 1 & 1.60 & 0.2238 \\
Season & 3 & 5.00 & 0.0124 \\
Habitat x Season & 3 & 13.52 & $\mathbf{0 . 0 0 0 1}$ \\
\hline
\end{tabular}

results also showed a clear segregation of the run and riffle benthic assemblages.

Few research studies have considered changes in the drift among fluvial habitats of mountain streams (Leung et al., 2009). In the drift of Achiras stream, diversity and evenness did not differ between riffle and run. These data indicate that the transporting of macroinvertebrates downstream homogenize the spatial faunal composition. However, the highest drift density was observed in run. The main contribution of drifting organisms in run is related to the high densities of other remote benthic habitats. Therefore, we agree with Waters (1965) who points out that the drift structure at a given stream point depends not only on local production but also on upstream distant areas. In other studies conducted in small and medium order streams of the northern hemisphere, the highest drift densities were observed in riffles (Leung et al., 2009; Rader, 1997).

Conducting this study, we found that the structural organization of the drift and benthic macroinvertebrate community shows different patterns of variation at spatial and temporal scales.
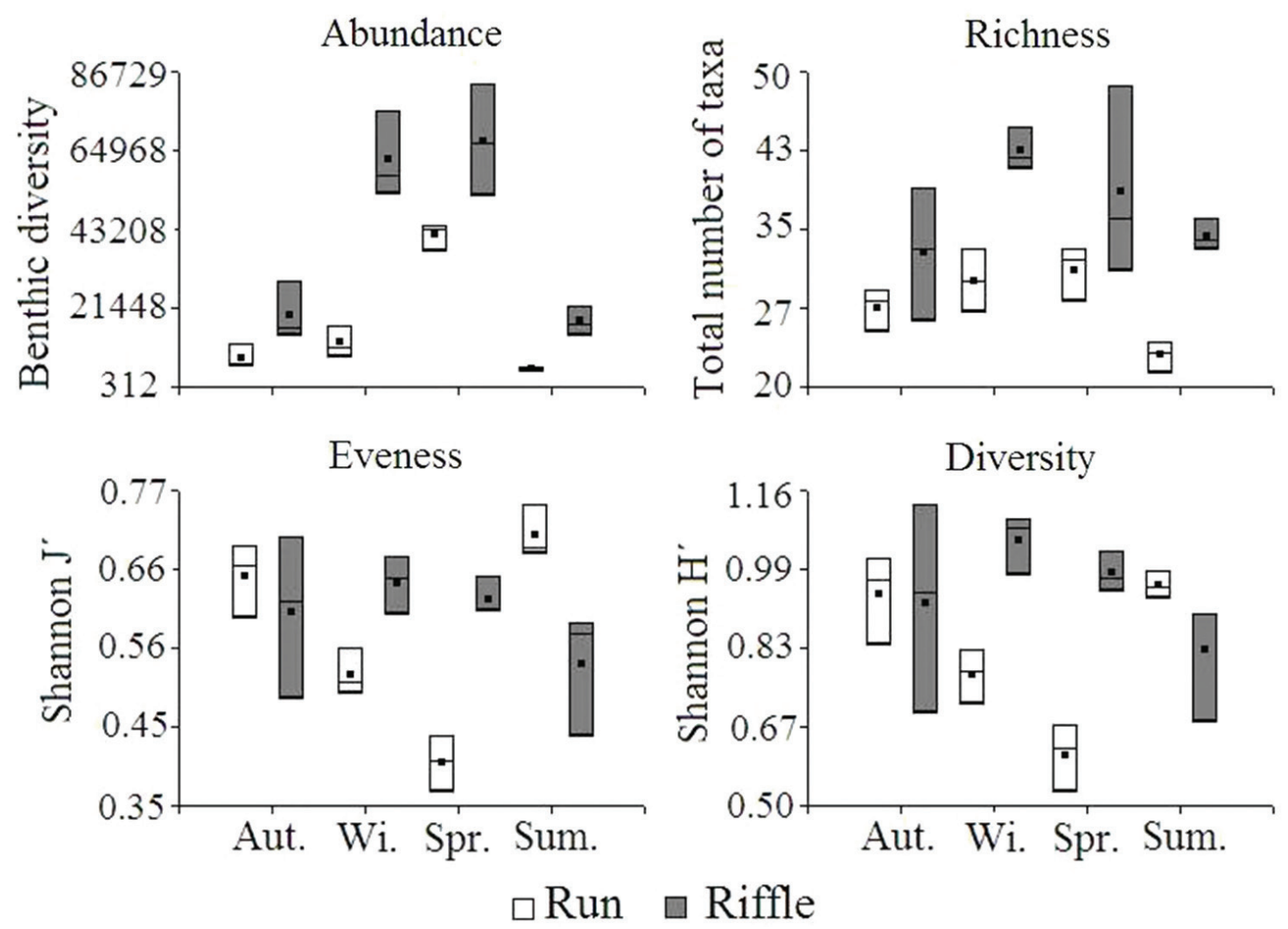

Figure 6. Box plots for macroinvertebrate benthic abundance, taxonomic richness, diversity and evenness in run and riffle of the study site. Seasons: autumn (Aut.), winter (Wi.), spring (Spr.) and summer (Sum.). 


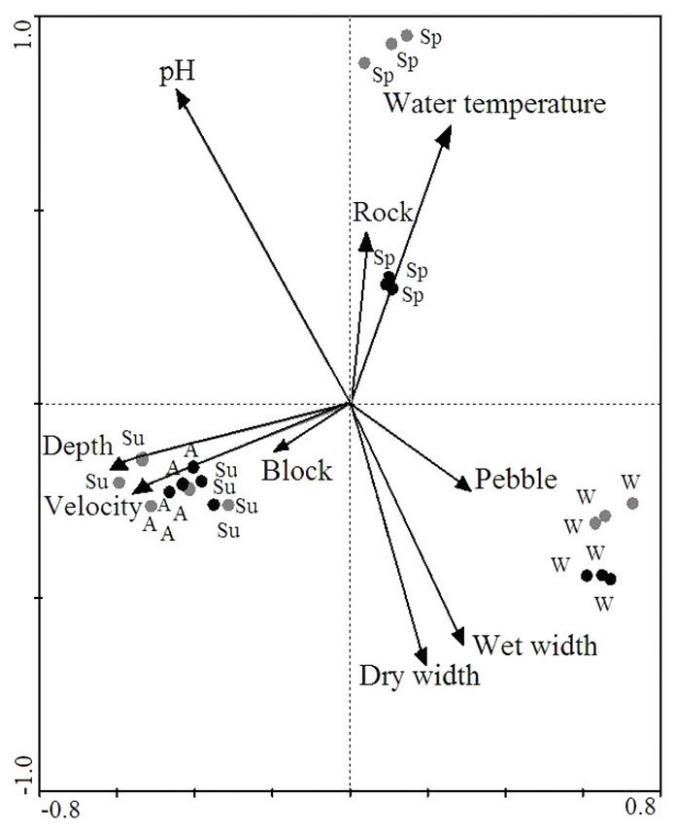

Figure 7. CCA ordination of drift samples and abiotic variables in Achiras stream. Habitats: run (O) and riffle (O). Seasons: autumn (A), winter (W), spring (Sp) and summer $(\mathrm{Su})$.

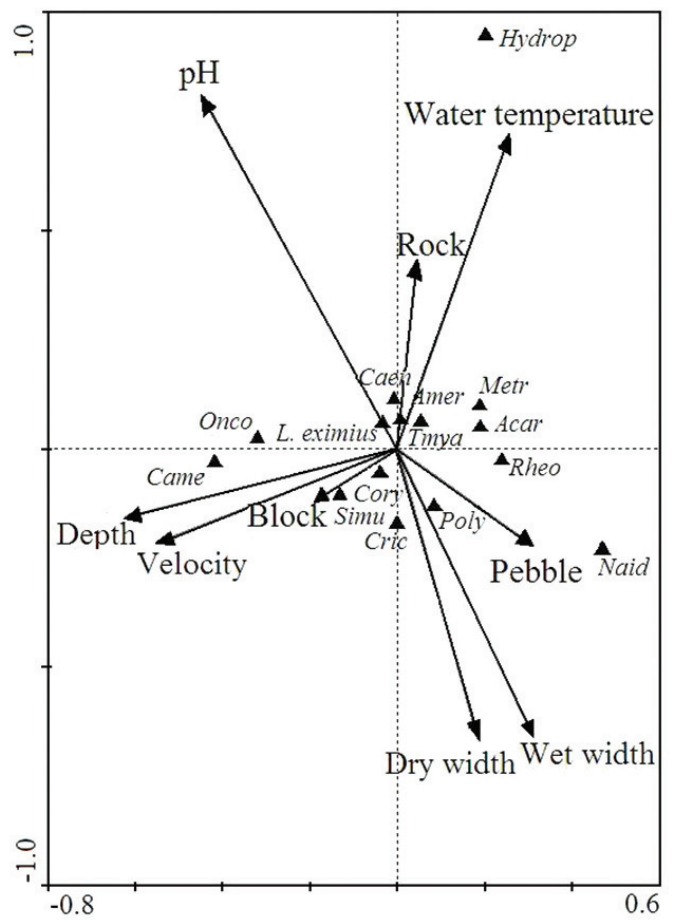

Figure 8. CCA ordination of drifting taxa and abiotic variables in Achiras stream. Naid: Naidinae, Acar: Acariformes, Amer: Americabaetis sp., Came: Camelobaetidius penai, Caen: Caenis sp., L. eximius: Leptohyphes eximius, Hydrop: Hydroptila sp., Metr: Metrichia sp., Simu: Simulium sp., Poly: Polypedilum sp., Rheo: Rheotanytarsus sp., Tmyia: Thienemannimyia sp., Cory: Corynoneura sp., Onco: Onconeura sp., Cric 3: Cricotopus sp. 3.
The importance of the drift process in providing information about the benthos upstream of a study site is demonstrated in our study by the registration of stoneflies and chironomids in the benthos of downstream sites where they are not usually found. So as to fully understand the ecological processes of

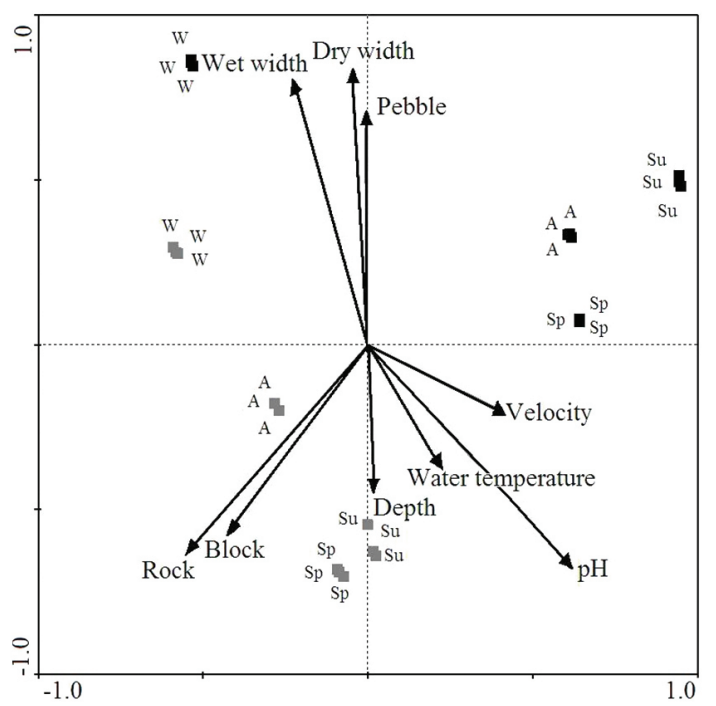

Figure 9. CCA ordination of benthic samples and abiotic variables in Achiras stream. Habitats: run $(\square)$ and riffle ). Seasons: autumn (A), winter (W), spring (Sp) and summer $(\mathrm{Su})$.

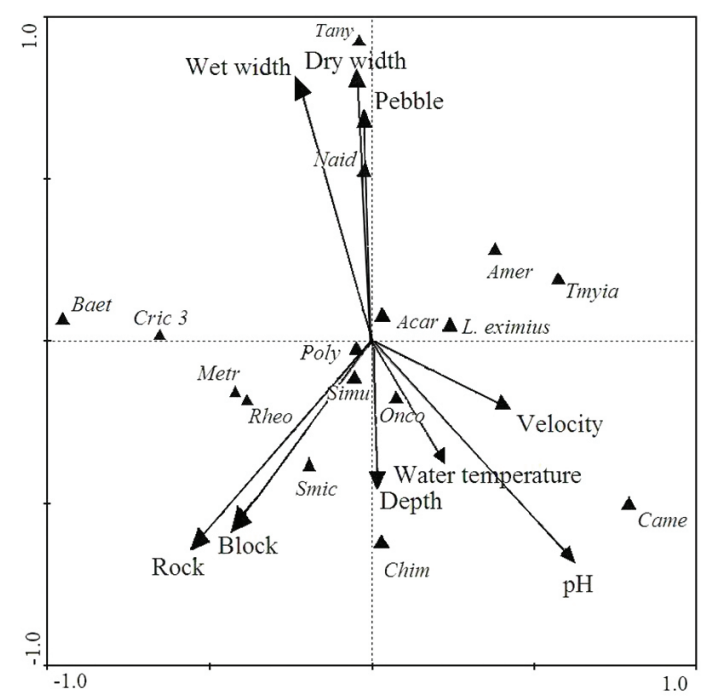

Figure 10. CCA ordination of benthic taxa and abiotic variables in Achiras stream. Naid: Naidinae, Acar: Acariformes, Amer: Americabaetis sp., Baet: Baetodes sp., Came: Camelobaetidius penai, L. eximius: Leptohyphes eximius, Chim: Chimarra sp., Smic: Smicridea sp., Metr: Metrichia sp., Simu: Simulium sp., Poly: Polypedilum sp., Tany: Tanytarsus sp., Rheo: Rheotanytarsus sp., Tmyia: Thienemannimyia sp., Onco: Onconeura sp., Cric 3: Cricotopus sp. 3. 
the stream community, research must incorporate the study of drift in the conventional fluvial benthic survey.

\section{Acknowledgements}

The present research was supported by Secretaría de Ciencia y Técnica, Universidad Nacional de Río Cuarto. We specially acknowledge to Mrs. R. P. Ison, for her constructive comments on the manuscript, and to M. Boccolini, G. Raffaini, P. Ffrench, J. Zanotto and J. Márquez for their assistance in field and laboratory tasks.

The authors thank Miss V. Barjacoba for her contribution in improving the English language in this study. Finally we would like to show express our gratitude to the anonymous referees whose suggestions contributed greatly to improve the early manuscript.

\section{References}

ALLAN, J.D. 1995. Stream ecology: structure and function of running waters. London: Chapman $\&$ Hall. 388 p. http://dx.doi.org/10.1007/978-94011-0729-7

BOYERO, L. and BOSCH, J. 2002. Spatial and temporal variation of macroinvertebrate drift in two Neotropical streams. Biotropica, vol. 34, no. 4, p. 567-574.

BROOKS, AJ., HAEUSLER, T., REINFELDS, I. and WILLIAMS, S. 2005. Hydraulic microhabitats and the distribution of macroinvertebrates assemblages in riffles. Freshwater Biology, vol. 50, p. 331-344. http:// dx.doi.org/10.1111/j.1365-2427.2004.01322.x

CORIGLIANO, MC., GUALDONI, CM., OBERTO, AM. and RAFFAINI, GB. 1998. Atributos estructurales de la deriva de invertebrados en el río Chocancharava, Córdoba, Argentina. Ecología Austral, vol. 8, p. 5-12.

CORIGLIANO, MC., GUALDONI, CM., OBERTO, AM. and RAFFAINI, GB. 2001. Longitudinal distribution of the mayfly (Ephemeroptera) communities at the Chocancharava river basin (Córdoba, Argentina). In DOMINGUEZ, E., ed. Trends in Research in Ephemeroptera and Plecoptera. Kluwer Academic, Plenum Publishers.

DEGIOVANNI, S. 2005. Análisis de problemas geoambientales vinculados a los recursos hídricos en la cuenca del arroyo Achiras-del Gato. In BLARASIN, M., DEGIOVANNI, S., CABRERA, A. and VILLEGAS, M., eds. Aguas superficiales y subterráneas en el sur de Córdoba: una perspectiva geoambiental. Río Cuarto: U.N.R.C. p. 181-222.

DOMÍNGUEZ, E. and FERNÁNDEZ, HR., eds. 2009. Macroinvertebrados bentónicos sudamericanos.
Sistemática y biología. Tucumán: Fundación Miguel Lillo. 656 p.

ELLIOTT, JM. 1970. Methods of sampling invertebrate drift in running water. Annales de Limnologie, vol. 6, p. 133-159. http://dx.doi.org/10.1051/ $\operatorname{limn} / 1970017$

GLADSØ, BJA. and RADDUM, GG. 2002. Rotenone treatment of a west Norwegian river: effects on drift of invertebrates. Verhandlungen des Internationalen Verein Limnologie, vol. 28, p. 764-769.

GUALDONI, CM., OBERTO, AM., RAFFAINI, GR. and CORIGLIANO, MC. 1991. Fluctuaciones espacio-temporales de la deriva en un río de llanura. Biología Acuática, vol. 15, no. 2, p. 224-225.

GUALDONI, CM. and OBERTO, AM. 2012. Estructura de la comunidad de macroinvertebrados del arroyo Achiras (Córdoba, Argentina): análisis previo a la construcción de una presa. Iheringia Série Zoologia, vol. 102, no. 2, p. 177-186

HYNES, HBN. 1970. The ecology of running waters. University of Toronto Press, Toronto, $555 \mathrm{p}$.

JERGENTZ, S., MUGNI, H., BONETTO, C. and SCHULTZ, R. 2004a. Runoff-related endosulfan contamination and aquatic macroinvertebrate response in rural basins near Buenos Aires, Argentina. Archives of Environmental Contamination and Toxicology, vol. 46, no. 3, p. 345-352. PMid:15195806. http://dx.doi.org/10.1007/s00244-003-2169-8

JERGENTZ, S., PESSAQ, P., MUGNI, H., BONETTO, C. and SCHULTZ, R. 2004b. Linking in situ bioassays and population dynamics of macroinvertebrates to assess agricultural contamination in streams of the Argentine pampa. Ecotoxicology and Environmental Safety, vol. 59, no. 2, p. 133-141. PMid:15327868. http://dx.doi.org/10.1016/j.ecoenv.2004.06.007

LEUNG, ES., ROSENFELD, JS. and BERNHARDT, JR. 2009. Habitat effects on invertebrate drift in a small trout stream: implications for prey availability to drift-feeding fish. Hidrobiologia, vol. 623, p. 113125. http://dx.doi.org/10.1007/s10750-008-9652-1

MALMQUIST, HL., ANTONSSON, T., GUDBERGSSON, G., SKÜLASON, S. and SNORRASON, SS. 2000. Biodiversity of macroinvertebrates on rocky substrate in the surf zone of Iceland lakes. Verhandlungen des Internationalen Verein Limnologie, vol. 27, p. 121- 127.

OBERTO, AM., RAFFAINI, GB. and CORIGLIANO, MC. 2004. Diel variations in macroinvertebrate drift in a mountain stream. Acta Limnologica Brasiliensia, vol. 16, no. 2, p. 175-182.

POFF, LN. and WARD, JV. 1991. Drift responses of benthic invertebrates to experimental stream flow variation in a hidrologically stable stream. Canadian Journal of Fisheries and Aquatic Sciences, vol. 48, p. 1926-1936. http://dx.doi.org/10.1139/f91-229 
PRINCIPE, RE. and CORIGLIANO, MC. 2006. Benthic, drifting and marginal macroinvertebrate assemblages in a lowland river: temporal and spatial variations and size structure. Hydrobiologia, vol. 553, p. 303-317. http://dx.doi.org/10.1007/s10750-0050694-3

PRINCIPE, RE. 2008. Taxonomic and size structures of aquatic macroinvertebrate assemblages in different habitats of tropical streams, Costa Rica. Zoological Studies, vol. 47, no. 5, p. 525-534.

RADER, RB. 1997. A functional classification of the drift: traits that influence invertebrate availability to salmonids. Canadian Journal of Fisheries and Aquatic Sciences, vol. 54, p. 1211-1234. http://dx.doi. org/10.1139/f97-025

RAMÍrEZ, A. and PRINGLE, CM. 1998 a. Invertebrate drift and benthic community dynamics in a lowland neotropical stream, Costa Rica. Hydrobiologia, vol. 386, p. 19-26. http://dx.doi. org/10.1023/A:1003409927131

RAMÍREZ, A. and PRINGLE, CM. 1998b. Structure and production of a benthic insect assemblage in a neotropical stream. Journal of the North American Benthological Society, vol. 17, no. 4, p. 443-463. http://dx.doi.org/10.2307/1468365

RAMÍREZ, A. and PRINGLE, CM. 2001. Spatial and temporal patterns of invertebrate drift in streams draining a neotropical landscape. Freshwater Biology, vol. 46, p. 47-62.

SHEARER, KA., HAYES, JW. and STARK, JD. 2002. Temporal and spatial quantification of aquatic invertebrate drift in the Maruia River, South Island, New Zealand. New Zealand Journal of Marine and Freshwater Research, vol. 36, p. 529-536. http:// dx.doi.org/10.1080/00288330.2002.9517108

STARK, JD., SHEARER, KA. and HAYES, JW. 2002. Are aquatic invertebrate drift densities uniform? Implications for salmonid foraging models. Verhandlungen des Internationalen Verein Limnologie, vol. 28, p. 988-991.

SVENDSEN, CR., QUINN, T. and KOLBE, D. 2004. Review of Macroinvertebrate Drift in Lotic Ecosystems. Seattle: Wildlife Research Program, Environmental and Safety Division. $92 \mathrm{p}$.

TER BRAAK, CJF. and. SMILAUER, P. 1999. Canoco for Windows (Version 4.02) - a Fortran Program for Canonical Community Ordination. Wageningen: Centre for biometry Wageningen.

VALENZUELA, MC., SOSA, EC. and GÓMEZ, O. 1998. Una aproximación a la caracterización de los macroambientes del sur cordobés. El espacio serrano. CRONIA - Revista de Investigación de la Facultad de Ciencias Humanas, vol. 2, no. 2, p. 128-138.

WATERS, TF. 1965. Interpretation of invertebrate drift in stream. Ecology, vol. 46, no. 3, p. 327-334. http:// dx.doi.org/10.2307/1936336

WATERS, TF. 1972. The drift of stream insects. Annual Review of Entomology, vol. 17, p. 253-272. http:// dx.doi.org/10.1146/annurev.en.17.010172.001345

Received: 02 March 2012 Accepted: 11 November 2013 